\title{
Specific edge effects in highly endangered Swartland Shale Renosterveld in the Cape Region
}

\author{
Effets de lisières spécifiques dans les Swartland Shale Renosterveld, \\ formation arbustive en voie de disparition \\ de la région du Cap en Afrique du Sud
}

\author{
Anne HORN ${ }^{1 *}$, Cornelia B. KRUG ${ }^{2}$, lan P. NEWTON ${ }^{3}$ and Karen J. ESLER ${ }^{1,4}$ \\ 1. Department of Conservation Ecology and Entomology, Stellenbosch University, \\ Private Bag X1, Matieland 7602, Stellenbosch, RSA \\ 2. Department of Zoology, University of Cape Town, \\ Rondebosch 7700, Cape Town, RSA, cbkrug@gmail.com \\ 3. Department of Archaeology, University of Cape Town, \\ Private Bag, Rondebosch 7701, Cape Town, RSA, ian.newton@uct.ac.za \\ 4. Centre of Excellence for Invasion Biology, Faculty of Science, Natural Sciences Building, \\ Private Bag X1, University of Stellenbosch, Matieland 7602, RSA, kje@sun.ac.za \\ * Corresponding author: Düsseler Höhe 22, 42327 Wuppertal, \\ Germany, Cell: + 49178 2127618, Fax: + 492104957495 \\ E-mail: email.ahorn@googlemail.com
}

\begin{abstract}
The critically endangered Renosterveld shrubland of the Cape Floristic Region in South Africa is one of the most transformed vegetation types in the world. The mostly small patches that remain after the extensive fragmentation are potentially vulnerable to edge effects and therefore, information on the extent of edge effects in this vegetation type is urgently required for conservation planning. To provide this information, we studied edge effects at two sites in each of five larger fragments of Swartland Shale Renosterveld near Cape Town surveying the vegetation composition along three $10 \mathrm{~m}$ wide and $200 \mathrm{~m}$ long belt transects. There was little indication of edge effects among the dominant woody species. However, abundance and/or species richness of the petaloid monocotyledonous plants, which contribute a disproportionally high fraction of the vegetation type's high biodiversity, as well as the ferns, had a clear negative correlation with edge proximity. For these taxa, effects did not level off at the end of the transect at $200 \mathrm{~m}$. This extent of impact is much larger than those reported in most other studies on edge effects among
\end{abstract}

Keywords: Fragmentation, geophytes, mediterranean-type shrubland, petaloid monocotyledonous plants, reserve size and shape. plants. In contrast, species indicative of high disturbance levels generally decreased within the first $30 \mathrm{~m}$. Consequently, Swartland Shale Renosterveld fragments would be likely to benefit from being enlarged to over $400 \mathrm{~m}$ width, while corridors or stepping stones should have a width of over $60 \mathrm{~m}$ to minimize major edge effects.

\section{Introduction}

Edge effects are a generally well researched phenomenon (Saunders et al. 1991) and can have large scale detrimental impacts. Average reported values for depth of edge influence are $60 \mathrm{~m}$ for abiotic factors (Harrison \& Bruna 1999; Matlack 1993), 50 m for plants, $100 \mathrm{~m}$ for invertebrates and 50 to $200 \mathrm{~m}$ for birds (reviewed by Ries et al. 2004). Physical factors are claimed to be the predominant cause for the negative effects that fragmentation has on biodiversity (Harrison \& Bruna 1999). Edge effects have been intensely researched in temperate and tropical forests (Murcia 1995), but to date very little has been published on vegetation responses in mediter- 
ranean-type shrublands with the notable exception of the study by Hester and Hobbs (1992), who found indistinct edge effects on native annual plants in shrublands in the Western Australian wheat-belt reaching up to $60 \mathrm{~m}$ into the fragment.

South African West Coast Lowland Renosterveld, a shrubland vegetation type within the highly diverse Cape Floristic Region, has been intensively transformed within the past 300 years, reduced to between $3 \%$ and $9.4 \%$ of its original extent (depending on the study and definition of vegetation type) and split into a large number of small fragments (Low \& Rebelo 1996; McDowell \& Moll 1992; Newton \& Knight 2005; von Hase et al. 2003). Therefore, edge effects are likely to impact on much of the remaining habitat, but so far have only been studied in two unpub-

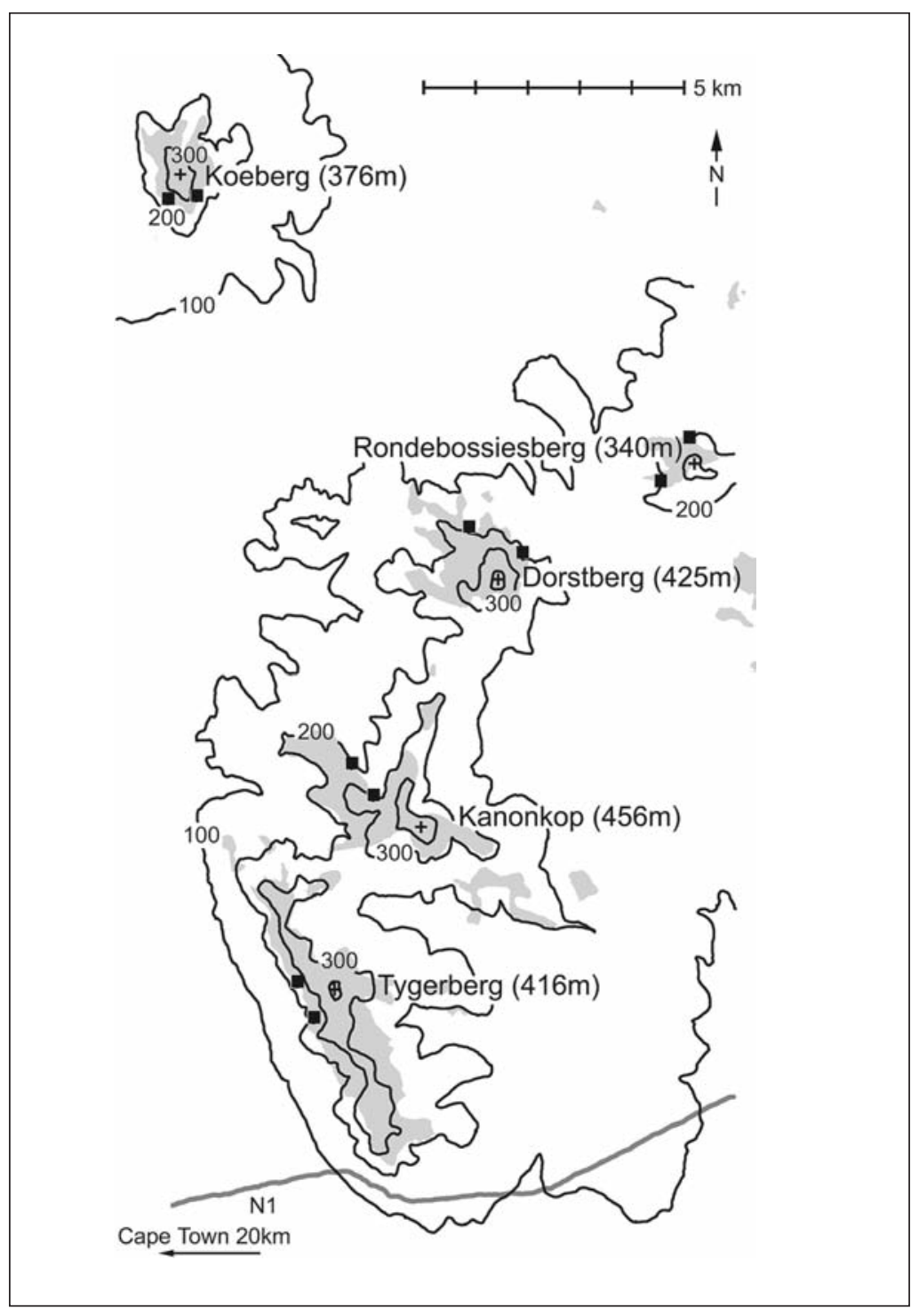

Figure 1 - Study area with extent of Renosterveld (shaded in grey) and sampling sites (-). lished M. Sc. theses (De Villiers et al. 2003; Muhl 2008) focusing on the effects of alien grass invasion.

To make recommendations for the conservation of Renosterveld, we investigated how far edge effects extended into the fragments and what plant groups and species were affected. This information was then used to suggest a minimum width for fragments to receive the highest conservation priority, to what size smaller fragments should be enlarged for the inclusion of core habitat, and how wide corridors and stepping stones would need to be to include non-edge dominated habitat.

\section{Study Area}

The study was conducted in the Tygerberg Hills, which lie just North-East of the Cape Town city centre in the Western Cape Province of South Africa (Figure 1). This area was chosen in the context of the Tygerberg remnants initiative (Table Mountain Fund/World Wildlife Fund) to provide information for conservation planning and because it contains some of the largest remaining fragments of West Coast Renosterveld.

Renosterveld is a vegetation type dominated by asteraceous shrubs and grasses, the prehistorical balance of which is still under debate (Krug et al. 2004; Low \& Rebelo 1996; Rebelo 1995; Stock et al. 1993). Geophytes occur in high numbers and contribute disproportionally to the high local species diversity (Moll et al. 1984; Procheș et al. 2005; Ruiters 2001). The vegetation in the study area is classified as "Swartland Shale Renosterveld" by Rebelo et al. (2006) and described as follows: "Low to moderately tall leptophyllous shrubland of varying canopy cover dominated by [Dicerothamnus rhinocerotis]."

\section{Methods}

\section{Survey design}

All fragments within the study area with a minimum diameter of $500 \mathrm{~m}$ were selected for the survey to ensure a gradient length of $200 \mathrm{~m}$. All five fragments were less than $700 \mathrm{~m}$ wide. Total fragment size varied from 80 ha to 600 ha. Grazing of livestock within 
the fragments was similar, but varied between years for all fragments. Some fragments were fenced off, whereas others were not or had fences running through the vegetation into the patch. In addition, fences had been put up at different times.

On each fragment, two sites were selected with linear edges bordering pastures or fields, with a distance to the next natural vegetation patern greater than $1 \mathrm{~km}$ (Fernández et al. 2002) and with at least $100 \mathrm{~m}$ between them. All selected sites had uphill gradients and a post-fire age of over 30 years. At each site, three belt-transects of $10 \mathrm{~m}$ width, spaced $10 \mathrm{~m}$ apart were surveyed. The start and end points of every woody species were recorded along line transects (running parallel to the edge) at $1 \mathrm{~m}, 2 \mathrm{~m}, 5 \mathrm{~m}, 10 \mathrm{~m}, 20 \mathrm{~m}, 50 \mathrm{~m}$, $100 \mathrm{~m}$ and $200 \mathrm{~m}$ from the edge of the fragment into the centre (Figure 2). Since individuals of different species were overlapping, total distance covered could be over ten meters. In addition, the dominant species or taxa in the herb layer were noted. Among the grasses and petaloid monocotyledonous species, identification was not possible for some species that were not in flower, so for consistency all species within these taxa were categorized as "grasses" and "petaloid monocotyledons", respectively. "Petaloid monocotyledons" are defined here as monocotyledonous plants with large, showy flowers, which are mostly pollinated by animals, and are treated as consistent with monocotyledonous geophytes.

Results from the three line transects at one site with the same distance from the edge were averaged for each site to avoid pseudoreplication (Hurlbert 1984).

\section{Analysis}

All data were tested for normality with the Shapiro Wilk's W-Test and analyzed accordingly. To test for significance of edge effects, we used either a parametric ANOVA $(\mathrm{F})$ or a Kruskal-Wallis ANOVA by rank $(\mathrm{H})$ and Pearson correlation (r) or Spearman rank correlation (r) tests. With these tests, we analyzed only species or taxa recorded in at least 10 of all 240 linear transects for statistic validity. For species richness analyses, we used all identified species and grouped all other species into a "non-identified" category. Species numbers are therefore minimum values only.

\section{Results}

A list of all species identified to species' level showing their occurence on the transects and including their distribution area can be found in the appendices A-C. The most common woody species Dicerothamnus (previously Elytropappus) rhinocerotis and Eriocephalus africanus did not respond significantly to distance from the fragment edge; nor did the amount of bare ground (Figure 3). Only one of the woody species occurring in more than 25 plots, Helichrysum patulum, showed a significant increase in cover with increasing distance from the edge. However, a number of woody species occurring in 10 to 25 plots did exhibit significant trends (Spearman $\mathrm{R}$ $> \pm 0.25, \mathrm{p}<0.05)$, i.e. Asparagus capensis and Euryops thunbergii, which increased in cover with distance from the edge, and Athanasia trifurcata, Berkheya rigida, Leysera gnaphalodes and Otholobium hirtum, which decreased with distance from the edge.

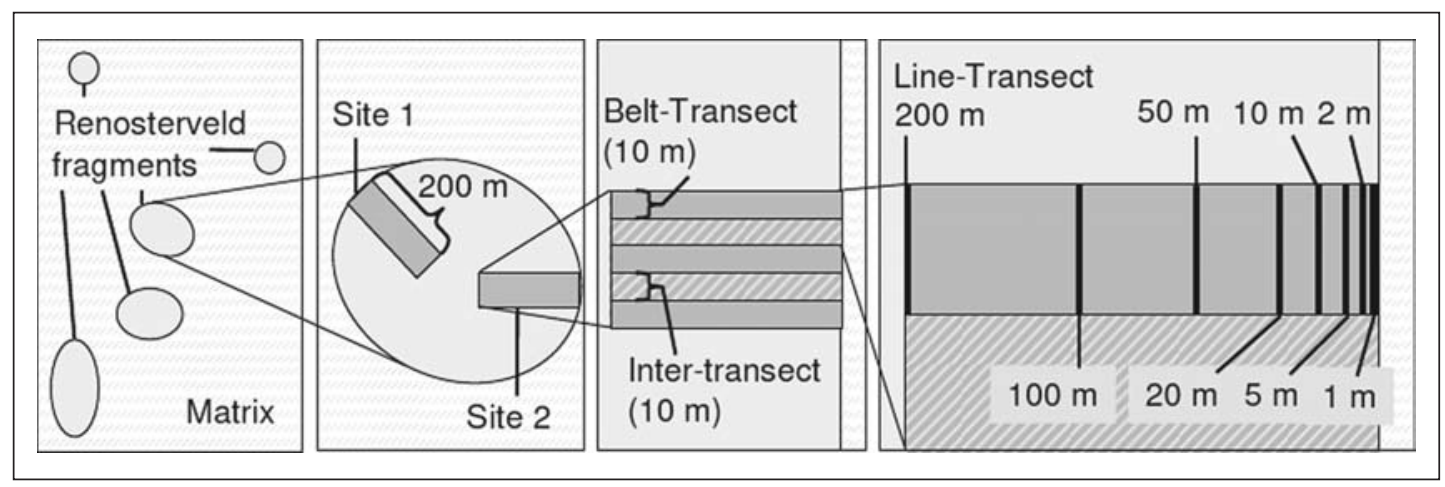

Figure 2 - Sampling design. 


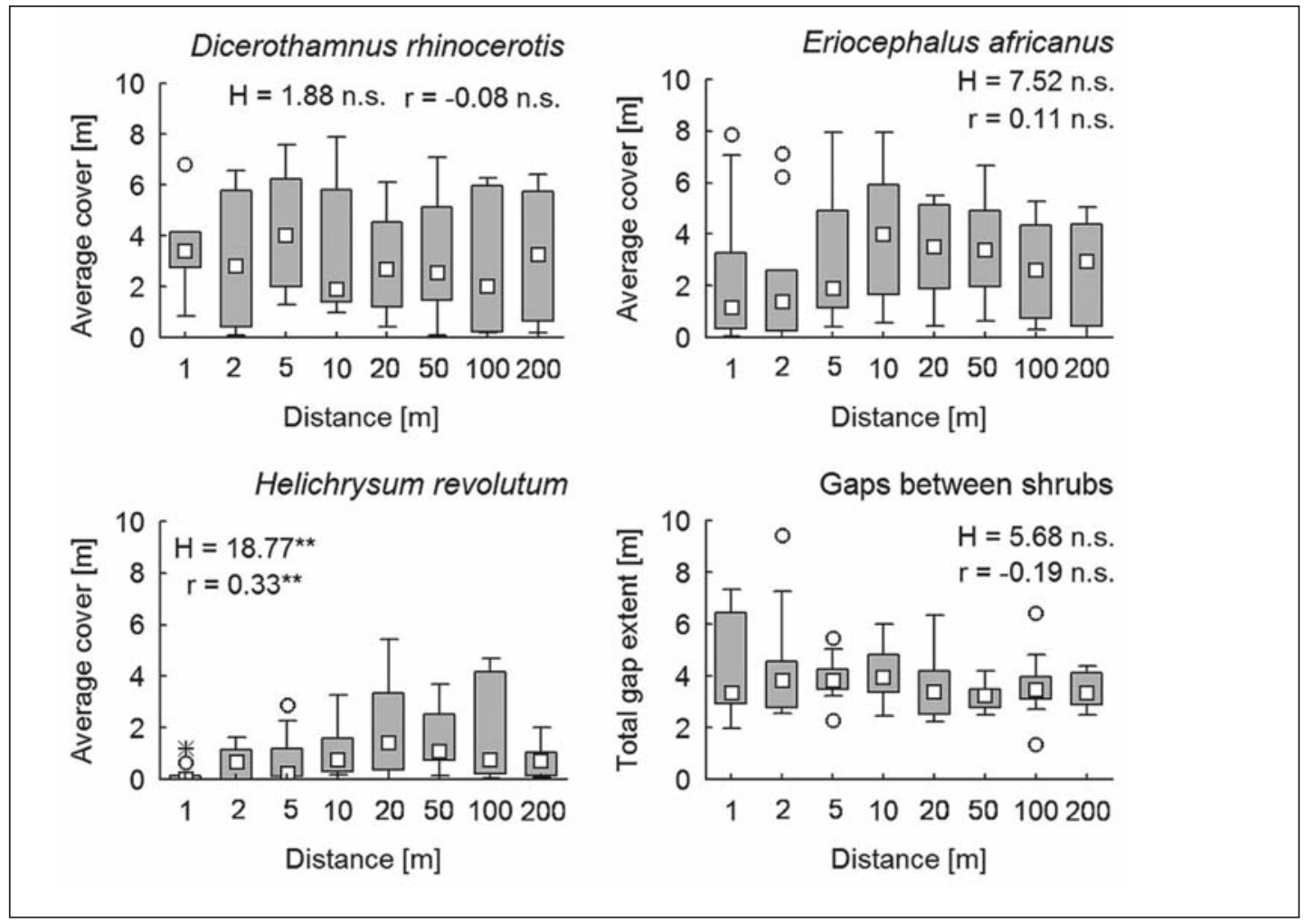

Figure 3 - Top left: Average cover of Dicerothamnus rhinocerotis per line transect per site. Top right: Average cover of Eriocephalus africanus per line transect per site. Bottom left: Average cover of Helichrysum revolutum per line transect per site. Bottom right: Average total extent of gaps per line transect per site.

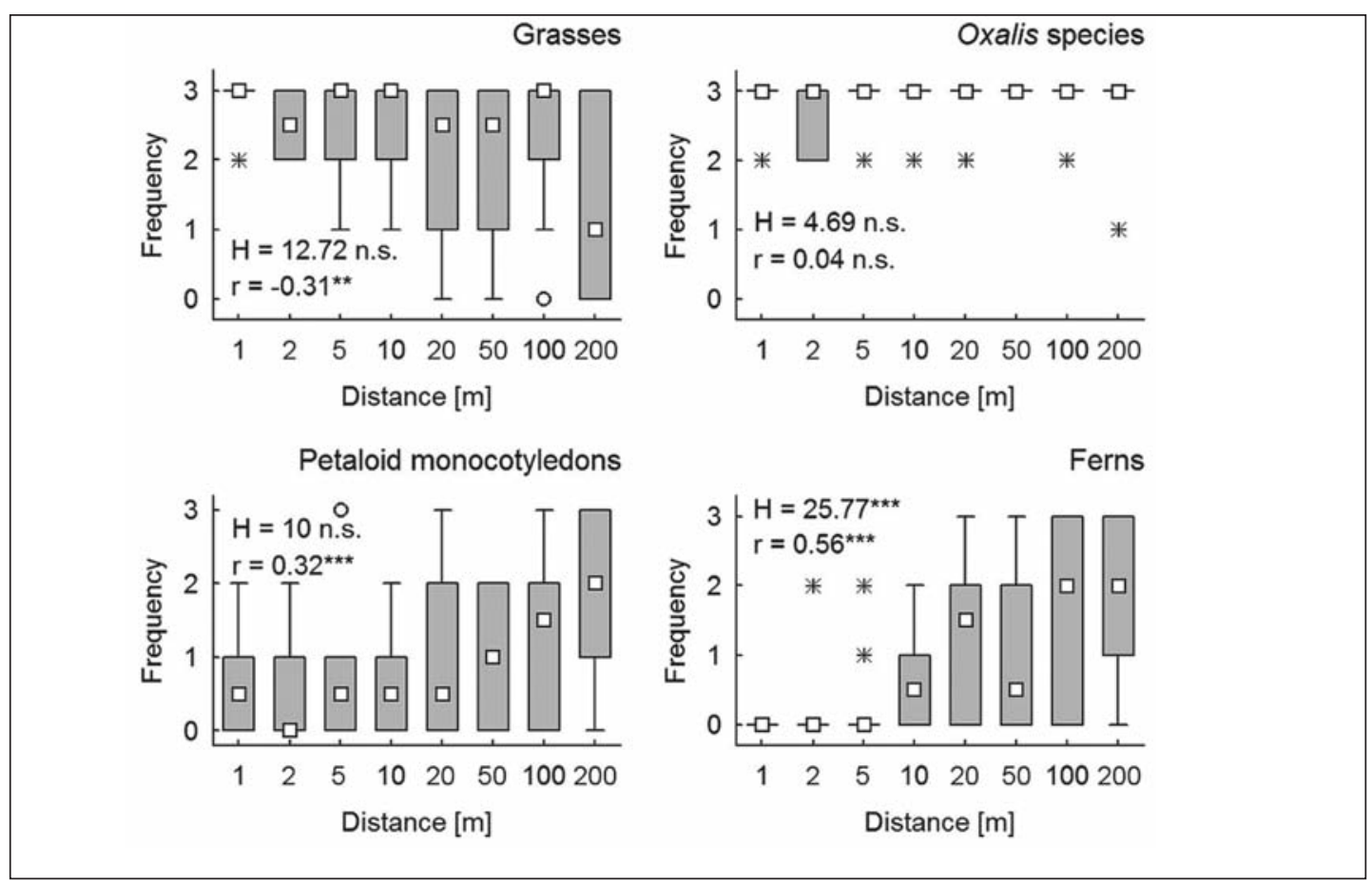

Figure 4 - Top left: Number of line transects per site that at least one grass species occurs in with at least 5 individuals.

Top right: Number of line transects per site that at least one Oxalis species occurs in with at least 5 individuals.

Bottom left: Number of line transects per site that at least one petaloid monocotyledon species occurs in with at least 5 individuals.

Bottom right: Number of line transects per site that at least one fern species occurs in with at least 5 individuals. 
Among the most common non-woody taxa, the Oxalis spp. were the only ones not displaying a significant response to distance from the edge of the fragment (Figure 4). While grasses in general showed a significant decline towards the fragment interior, petaloid monocotyledons (see Appendix) and ferns increased significantly with increasing distance from the edge. Among the taxa occurring in between 10 and 25 plots, only three responded significantly (Spearman $\mathrm{R}$ $> \pm 0.29, \mathrm{p}<0.05)$ : Anagallis arvensis, an

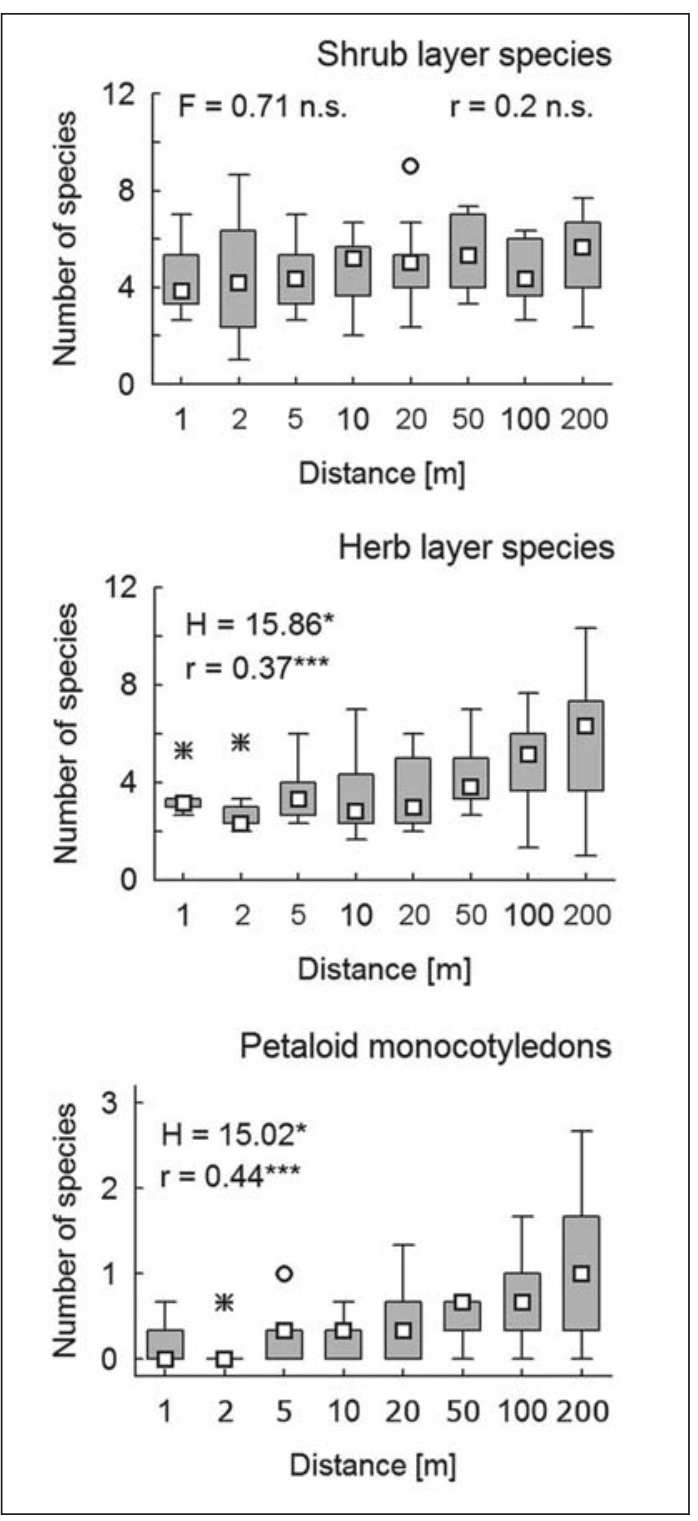

Figure 5 - Top: Average number of shrub layer species occurring in the three linear transects at one site.

Centre: Average number of herb layer species occurring in the three linear transects at one site with at least 5 individuals per transect.

Bottom: Average number of petaloid monocotyledon species occurring in the three linear transects at one site with at least 5 individuals per transect. alien, and Senecio arenarius exhibited significant increases, while Vicia sativa, another alien plant, decreased significantly with distance from the edge. The other two common alien species (Erodium moschatum and Fumaria muralis) did not respond to increasing distance from the fragment edge.

Whereas shrub layer species richness did not respond to increasing distance from the edge, species richness of all dominant herbaceous taxa in general and petaloid monocotyledons in particular showed a strong positive correlation (Figure 5).

\section{Discussion}

While dominant woody species and many common herbs did not show a clear effect of distance from the fragment edge, a number of plant taxa did; most notably, fern and petaloid monocotyledon abundance and/or species richness increased with distance and did not appear to approach saturation at the end of the transect at $200 \mathrm{~m}$, so it is possible that the edge effects would be more extensive in larger fragments. With a buffer zone of $200 \mathrm{~m}$, the core area in fragments over 3 ha would be reduced to only $11 \%$ of the currently remaining West Coast Renosterveld (including Swartland Shale, Swartland Silcrete, Swartland Granite, Swartland Alluvium and Peninsula Shale Renosterveld). However, about $20 \%$ of these edges constitute borders to other natural vegetation types and therefore are likely to respond in a less drastic way than the edges to transformed vegetation such as in our study.

In contrast, Hester and Hobbs (1992) found no clear response to edges for any species in shrublands of the Western Australian wheatbelt and Kemper et al. (1999) detected no effect of fragment size of on species richness in Renosterveld on the South Coast of South Africa, even though they were including fragments ranging from 0.06-153 ha. The discrepancies between our study and Kemper's results (1999) can possibly be explained as follows: common, but non-edge-sensitive species mask edge effects in multivariate analyses, and the grouping of dicotyledonous and monocotyledonous geophytes into one group clouds the various patterns within that group; in our study we found that the common and abundant Oxalis species (Dicotyle- 
dons) were unresponsive to edges. Also, a small number of petaloid monocotyledonous species were common at the edge (e.g. Moraea flaccida Sweet and Ornithogalum thyrsoides Jacq., A.H., unpublished data), which would further mask any gradient effects on the abundance of geophytes in general.

The extent of the edge effect on petaloid monocotyledons found in our study was much greater than reported in most other studies on plants (Ries et al. 2004). This indicates that edge effects were unlikely to be caused by abiotic factors alone (Harrison \& Bruna 1999). For the effect to be this clear on longlived petaloid monocotyledons (life span up to several decades for large bulbs, J. Manning, SANBI, personal communication) it is likely that the plants were suffering from increased mortality near the edges. Porcupines are known to feed on bulbs (Bragg et al. 2005; Skinner \& Smithers 1990) and thus are a potential factor in this context. They are known not to be deterred by transformed habitat or disturbance (personal communication with various farmers and personal observation) although they favor undisturbed habitats (Bragg et al. 2005). Other potential culprits include small mammals, such as mole rats (Reichman \& Jarvis 1989) as well as invertebrates such as Brachycerus weevils (Procheş et al. 2006). It is also possible that the above-ground parts of the plants were subject to herbivory, but no obvious grazing damage was noted during the course of this study or is generally known to be common (J. Manning, SANBI, personal communication).

Edge effects could also be acting on plant reproduction. For instance, Donaldson et al. (2002) demonstrated that pollination rates in four petaloid monocotyledonous species in Renosterveld decreased with fragment size. Also, Argentine ants can invade as far as $200 \mathrm{~m}$ into natural habitat (Bolger 2007; Suarez et al. 1998) and consume up to $42 \%$ of available nectar before pollinating insects can forage (Buys 1987). They are common in Renosterveld and have been reported to have an effect on invertebrate species composition in the Cape (Christian 2001; Lach 2007; Picker \& Samways 1996; Visser et al. 1996). It is therefore possible that there are edge effects on pollinator-plant interactions. However, asexual reproduction is common in some species and could buffer this effect (Pauw 2004; Pauw et al. 2004).
Edge effects on seed predation are highly species-specific and dependent on habitat preferences of local seed predators (Holl \& Lulow 1997; Jules \& Rathcke 1999; Ostfeld et al. 1997; Santos \& Telleria 1994), but small mammals from the matrix habitat can harvest seeds up to 200 to $500 \mathrm{~m}$ into a fragment (Laurance 1994), so an effect on seeds of petaloid monocotyledons (or other species) up to this distance is possible.

Edge effects on germination and plant establishment have equally complex, species-specific results (Cadenasso \& Pickett 2000; López-Barrera et al. 2005; Meiners et al. 2002). Competition with alien grasses, which are more common within 20 to $40 \mathrm{~m}$ of the edge (see also De Villiers et al. 2003; P. Holmes, personal communication), was shown to reduce establishment rates and decrease productivity in a number of Renosterveld species (Midoko-Ipongo et al. 2005; Muhl 2008). Furthermore, Vlok (1988) showed strong negative effects on general species richness of herbaceous species as well as geophytes and their abundance in lowland Fynbos and Renosterveld habitats. Since alien grass invasion only reaches less than $60 \mathrm{~m}$ into the fragments, this could only partially explain the extensive edge effects on petaloid monocotyledons.

Finally, ploughing can be a major factor influencing petaloid monocotyledon occurrences (Galil 1970; Hammouda et al. 2003). Edges in the study area have not been stationary since farming started in the area about 300 years ago and Talbot (1947) describes slopes of $14^{\circ}$ and steeper being ploughed in the 1930s and 40s with the Tygerberg being mentioned as an example specifically affected by this. For formerly ploughed areas geophyte numbers could be reduced, as old-field succession has been reported to be particularly slow for geophytes (Krug \& Krug 2007; Shiponeni 2003; Walton 2006).

\section{Implications}

From the results of our study and comparisons with other studies, we had to conclude that edge sensitivity cannot be easily inferred from other similar vegetation types or from one taxon to another. Edge response needs to be determined individually for each vegetation type or target species.

Considering our small sample size and exclusion of potentially relevant factors such as soil 
types, our study should be interpreted as a first but important step towards the determination of minimum patch sizes and effective corridor widths for the sustainable conservation of critically endangered Swartland Shale Renosterveld. Based on our results, we believe that smaller Renosterveld patches would benefit from being enlarged to a minimum width of over $400 \mathrm{~m}$ (ideally at least $800 \mathrm{~m}$ ) to provide core habitat for the conservation of the species rich petaloid monocotyledons. For corridors and stepping stones we recommend a minimum width of over $60 \mathrm{~m}$ (ideally at least $120 \mathrm{~m}$ ) to include a zone where edge species and alien grasses are not dominant. However, in agreement with Pressey et al. $(1994,1996)$ and Piessens et al. (2006), we must stress that even smaller patches can be important and worthy of conservation since core species do also currently occur there, albeit in lower numbers. Moreover, some unique micro-habitats with associated endemic species occur on small fragments only (Custodians of Rare and Endangered Wildflowers, South African Biodiversity Institute, unpublished data).

Further studies are essential and should include other taxa and a larger number of fragments to understand the effect of edges on the whole ecosystem and increase sample size for statistical validity. Ideally, fragments over $800 \mathrm{~m}$ in width should be studied to determine maximum edge effect extents, but since appropriate potential study sites of Swartland
Shale Renosterveld are few and far between, this would most probably mean expanding into other types of Renosterveld. Finally, for conservation practitioners to effectively manage the ecological processes that cause edge effects, these processes first need to be identified and understood for the target system or taxon. We therefore want to emphasize the urgency of conducting detailed studies on the impacts of edge-driven pollination, dispersal and establishment limitations and especially the effects of herbivory in Renosterveld (see also Kongor 2009).

\section{Acknowledgements}

A.H. \& C.B.K. were supported by a grant from the German Federal Ministry of Education and Research (01 LC 0624A2). A.H. was further supported through the Sub-Committee B fund of the University of Stellenbosch.

The authors would like to thank John Manning for providing critical information on petaloid monocotyledons. Patricia Holmes and two anonymous reviewers are thanked for their comments on an earlier version, which greatly improved this manuscript. And last, but not least, Cape Nature and all landowners are especially acknowledged for providing permits and allowing the work on their land respectively. 
Appendix 1 - List of woody species and their average cover in $\mathrm{cm}$ per $10 \mathrm{~m}$ transect at each distance from the edge of the fragment with species distribution area and endemism status.

\begin{tabular}{|c|c|c|c|c|c|c|c|c|c|}
\hline \multirow[t]{2}{*}{ species name } & \multirow[t]{2}{*}{ Distribution } & \multicolumn{8}{|c|}{ Distance from the edge in meters } \\
\hline & & 1 & 2 & 5 & 10 & 20 & 50 & 100 & 200 \\
\hline Anthospermum aethiopicum L. & SW to S Coast of South Africa & 6 & 14 & 18 & 15 & 12 & 28 & 65 & 70 \\
\hline Aspalathus ericifolia L. & SW Coast, Endemic to CFR* & 3 & 4 & 0 & 1 & 0 & 7 & 2 & 0 \\
\hline Asparagus capensis L. & $\begin{array}{l}\text { Southern Namibia and South } \\
\text { Africa }\end{array}$ & 1 & 0 & 0 & 2 & 0 & 2 & 7 & 23 \\
\hline Asparagus lignosus Burm.f. & Endemic to the CFR & 0 & 0 & 0 & 0 & 1 & 0 & 0 & 2 \\
\hline $\begin{array}{l}\text { Asparagus rubicundus } \\
\text { P.J.Bergius }\end{array}$ & SW South Africa & 0 & 0 & 0 & 0 & 0 & 0 & 0 & 2 \\
\hline Athanasia trifurcata (L.) L. & Endemic to the CFR & 83 & 64 & 59 & 5 & 12 & 3 & 1 & 0 \\
\hline $\begin{array}{l}\text { Berkheya rigida (Thunb.) } \\
\text { Adamson \& T.M. Salter }\end{array}$ & $\begin{array}{l}\text { Endemic to the CFR, often in } \\
\text { disturbed areas }\end{array}$ & 21 & 7 & 8 & 5 & 0 & 0 & 2 & 0 \\
\hline Chironia baccifera L. & South Africa & 2 & 4 & 6 & 11 & 23 & 8 & 28 & 16 \\
\hline $\begin{array}{l}\text { Chrysanthemoides incana } \\
\text { (Burm.f.) Norl. }\end{array}$ & Namibia and South Africa & 0 & 0 & 0 & 0 & 6 & 0 & 0 & 3 \\
\hline Chrysocoma ciliata L. & South Africa & 4 & 5 & 8 & 9 & 8 & 4 & 7 & 2 \\
\hline Cissampelos capensis L.f. & $\begin{array}{l}\text { Southern Namibia and South } \\
\text { Africa }\end{array}$ & 0 & 0 & 9 & 7 & 0 & 21 & 42 & 47 \\
\hline Clutia ericoides Thunb. & W to S Coast of South Africa & 0 & 0 & 0 & 0 & 1 & 10 & 25 & 2 \\
\hline Cyphia digitata (Thunb.) Willd. & W to S Coast of South Africa & 1 & 1 & 3 & 19 & 4 & 4 & 5 & 0 \\
\hline $\begin{array}{l}\text { Dicerothamnus minocerotis (L.f.) } \\
\text { Koek. }\end{array}$ & $\begin{array}{l}\text { = renosterbos, Southern } \\
\text { Namibia and South Africa }\end{array}$ & 214 & 203 & 252 & 249 & 207 & 255 & 211 & 259 \\
\hline Eriocephalus africanus L. & Coastal areas of South Africa & 232 & 216 & 316 & 377 & 335 & 349 & 260 & 253 \\
\hline $\begin{array}{l}\text { Euphorbia arceuthobioides } \\
\text { Boiss. }\end{array}$ & Namibia and South Africa & 0 & 0 & 0 & 0 & 14 & 8 & 0 & 0 \\
\hline Euryops thunbergii B.Nord. & Endemic to the CFR & 0 & 0 & 0 & 0 & 4 & 58 & 42 & 23 \\
\hline Felicia fruticosa (L.) G.Nichols. & South Africa & 29 & 32 & 29 & 53 & 94 & 89 & 81 & 39 \\
\hline Galenia africana $\mathrm{L}$. & W to SW South Africa & 55 & 41 & 16 & 7 & 24 & 62 & 36 & 10 \\
\hline Helichrysum patulum (L.) D.Don & Endemic to the CFR & 17 & 12 & 28 & 23 & 23 & 8 & 4 & 36 \\
\hline $\begin{array}{l}\text { Helichrysum revolutum (Thunb.) } \\
\text { Less. }\end{array}$ & $\begin{array}{l}\text { Southern Namibia to SW South } \\
\text { Africa }\end{array}$ & 21 & 67 & 78 & 108 & 189 & 154 & 169 & 71 \\
\hline Leysera gnaphalodes (L.) L. & $\begin{array}{l}\text { Southern Nambia and South } \\
\text { Africa }\end{array}$ & 16 & 24 & 7 & 2 & 1 & 0 & 6 & 0 \\
\hline Lycium afrum $\mathrm{L}$. & Endemic to the CFR & 0 & 1 & 0 & 2 & 1 & 0 & 4 & 0 \\
\hline Lycium ferocissimum Miers & Coastal areas of South Africa & 0 & 2 & 5 & 0 & 0 & 1 & 0 & 0 \\
\hline Melianthus major L. & Coastal areas of South Africa & 0 & 0 & 0 & 1 & 0 & 0 & 0 & 0 \\
\hline Microloma sagittatum (L.) R.Br. & W to S Coast of South Africa & 1 & 0 & 0 & 0 & 0 & 0 & 0 & 0 \\
\hline Muraltia heisteria (L.) DC. & Endemic to the CFR & 19 & 12 & 7 & 4 & 4 & 5 & 13 & 0 \\
\hline Olea capensis (Jacq.) Klotzsch & South Africa to tropical Africa & 0 & 0 & 0 & 0 & 0 & 0 & 0 & 1 \\
\hline Otholobium hirtum (L.) C.H.Stirt & $\begin{array}{l}\text { Renosterveld, Endemic to the } \\
\text { CFR }\end{array}$ & 55 & 35 & 10 & 5 & 6 & 11 & 0 & 1 \\
\hline Polygala garcinii DC. & Endemic to the CFR & 0 & 0 & 0 & 1 & 0 & 0 & 0 & 0 \\
\hline Pteronia divaricata (P.J.Bergius) & Southern Namibia to Tygerberg & & & & & & & & \\
\hline Less. & Hills & 2 & 19 & 40 & 23 & 36 & 10 & 12 & 33 \\
\hline $\begin{array}{l}\text { Putterlickia pyracantha (L.) } \\
\text { Szyszyl. }\end{array}$ & W to S Coast of South Africa & 0 & 0 & 0 & 0 & 0 & 2 & 0 & 7 \\
\hline Rhus dissecta Thunb. & Endemic to the CFR & 0 & 0 & 0 & 0 & 0 & 0 & 0 & 4 \\
\hline Rhus glauca Thunb. & W to S Coast of South Africa & 0 & 0 & 0 & 0 & 27 & 0 & 8 & 52 \\
\hline $\begin{array}{l}\text { Rhus laevigata Thunb. var. } \\
\text { laevigata }\end{array}$ & W to SW Coast of South Africa & 0 & 0 & 10 & 12 & 24 & 1 & 0 & 0 \\
\hline $\begin{array}{l}\text { Rhus laevigat a var. villosa (L.f.) } \\
\text { R.Fernandes }\end{array}$ & W to SW Coast of South Africa & 0 & 0 & 11 & 0 & 3 & 0 & 0 & 0 \\
\hline Salvia africana-lutea $\mathrm{L}$. & W to SW Coast of South Africa & 0 & 0 & 8 & 0 & 0 & 3 & 0 & 3 \\
\hline Solanum guienense $\mathrm{L}$. & W to SW Coast of South Africa & 0 & 0 & 10 & 42 & 9 & 13 & 0 & 9 \\
\hline Tetragonia fruticosa $\mathrm{L}$. & W to SW Coast of South Africa & 5 & 15 & 2 & 6 & 14 & 6 & 8 & 28 \\
\hline${ }^{\star} \mathrm{CFR}=$ Cape Floristic Reg & & & & & & & & & \\
\hline
\end{tabular}


Appendix 2 - List of dicotyledonous herbaceous species with number of line transects they occurred on (with a maximum of 30) at each distance from the edge of the fragment and species distribution area and endemism status.

\begin{tabular}{|c|c|c|c|c|c|c|c|c|c|}
\hline \multirow[t]{2}{*}{ species name } & \multirow[t]{2}{*}{ Distribution } & \multicolumn{8}{|c|}{ Distance from the edge in meters } \\
\hline & & 1 & 2 & 5 & 10 & 20 & 50 & 100 & 200 \\
\hline Anagallis arvensis $\mathrm{L}$. & Exotic & & & 3 & 2 & 4 & 8 & 5 & 6 \\
\hline $\begin{array}{l}\text { Arctopus monocanthus } \\
\text { Carmicheal ex. Sond. }\end{array}$ & Endemic to the CFR & & & & & & & & 1 \\
\hline Arctotis hirsuta (Harv.) Beauv. & Endemic to the CFR & & & 1 & 2 & 1 & & & 2 \\
\hline Avena sativa $\mathrm{L}$. & Exotic & & & 1 & & & 3 & 1 & 1 \\
\hline $\begin{array}{l}\text { Cheilanthes capensis (Thunb.) } \\
\text { Sw. }\end{array}$ & Southern Africa & & & & & & & 4 & 3 \\
\hline Cotula bipinnata Thunb. & West Coast of South Africa & 1 & & 1 & & 1 & & & \\
\hline Cotula turbinata (L.) Pers. & $\begin{array}{l}\text { Endemic to the CFR, often in } \\
\text { disturbed areas }\end{array}$ & & & & & & 1 & 1 & \\
\hline Crassula capensis (L.) Baill. & Endemic to the CFR & & & & & & & 1 & 1 \\
\hline Diascia diffusa (Thunb.) Benth. & Renosterveld, endemic to CFR & & & & & & & & 1 \\
\hline $\begin{array}{l}\text { Dimorphotheca pluvialis (L.) } \\
\text { Moench }\end{array}$ & $\begin{array}{l}\text { Southern Namibia to the SW } \\
\text { South Africa }\end{array}$ & 5 & 2 & 3 & 1 & & 1 & 3 & 4 \\
\hline Erodium moschatum (L.) L'Hér. & Exotic & 2 & 1 & 1 & 1 & & 1 & 2 & 2 \\
\hline Euphorbia mauritanica L. & Southern Africa & & & & & & & & 1 \\
\hline Felicia tenella (L.) Nees & Endemic to the CFR & & & & & & 3 & 4 & 6 \\
\hline Fumaria muralis Sond. ex Koch & Exotic & & & & 1 & 2 & 1 & 3 & 3 \\
\hline Hemimeris sabulosa L.f. & W to SW Coast of South Africa & 1 & 1 & 3 & 1 & 2 & 1 & 2 & 5 \\
\hline Indigofera heterophylla Thunb. & $\begin{array}{l}\text { Renosterveld, Coastal areas of } \\
\text { South Africa }\end{array}$ & 2 & 1 & & 3 & 1 & 2 & 2 & \\
\hline Medicago polymorphaL. & Exotic & & & & & & 1 & 1 & 1 \\
\hline Mohria cafforum (1.) Desv. & $\begin{array}{l}\text { Renosterveld, Western to } \\
\text { Eastern Cape of South Africa }\end{array}$ & & 2 & 3 & 7 & 13 & 11 & 14 & 17 \\
\hline $\begin{array}{l}\text { Nemesia barbata (Thunb.) } \\
\text { Benth. }\end{array}$ & W to SW Coast of South Africa & & & 1 & 1 & & 1 & 1 & 2 \\
\hline Oxalis argyrophylla T.M. Salter & Endemic to the CFR & & & 1 & & & & & \\
\hline Oxalis obtusa Jacq. & W to SW Coast of South Africa & 3 & 1 & & 3 & 4 & 5 & 3 & 5 \\
\hline Oxalis pes-caprae L. & Coastal areas of South Africa & 27 & 25 & 28 & 28 & 27 & 30 & 27 & 24 \\
\hline Oxalis purpurea L. & W to SW Coast of South Africa & 7 & 5 & 5 & 6 & 5 & 7 & 4 & 6 \\
\hline Oxalis tomentosa L.f. & Endemic to the CFR & & & & 2 & 1 & 1 & & 2 \\
\hline Spergularia media (L.) C.Presl & Exotic & & & 1 & & 1 & 1 & 4 & 2 \\
\hline Stachys aethiopica L. & South Africa & & & & & & & & 2 \\
\hline Tripteris clandestina Less. & W to SW Coast of South Africa & & & 2 & & & & 2 & 1 \\
\hline Ursinia nana D.C. & Coastal areas of South Africa & & & & & & & 2 & 3 \\
\hline
\end{tabular}


Appendix 3 - List of petaloid monocotyledonous species with number of line transects they occurred on (with a maximum of 30) at each distance from the edge of the fragment and species distribution area and endemism status.

\begin{tabular}{|c|c|c|c|c|c|c|c|c|c|}
\hline \multirow[t]{2}{*}{ Species name } & \multirow[t]{2}{*}{ Distribution } & \multicolumn{8}{|c|}{ Distance from the edge in meters } \\
\hline & & 1 & 2 & 5 & 10 & 20 & 50 & 100 & 200 \\
\hline $\begin{array}{l}\text { Albuca canadensis (L.) } \\
\text { F.M.Leight. }\end{array}$ & West Coast of South Africa & & & & & & & & 1 \\
\hline Babiana odarata L.Bolus & $\begin{array}{l}\text { Endemic to renosterveld, SW } \\
\text { coast of the CFR }\end{array}$ & & & & & & & & 2 \\
\hline $\begin{array}{l}\text { Hesperantha falcata (L.f.) Ker } \\
\text { Gawl. }\end{array}$ & Endemic to renosterveld, CFR & & & & & & 1 & & 2 \\
\hline Lachenalia unifolia Jacq. & $\begin{array}{l}\text { West Coast of South Africa, } \\
\text { locally frequent }\end{array}$ & & & & & 1 & & & 1 \\
\hline $\begin{array}{l}\text { Melaspherula ramosa (L.) } \\
\text { N.E.Br. }\end{array}$ & $\begin{array}{l}\text { Coastal areas from Southern } \\
\text { Namibia to the Eastern Cape of } \\
\text { South Africa, locally frequent }\end{array}$ & & & 1 & 1 & & & & 1 \\
\hline Moraea ciliata (L.f.) Ker Gawl. & $\begin{array}{l}\text { Western Cape of South Africa } \\
\text { and adjacent areas }\end{array}$ & & & & & 1 & & & \\
\hline Moraea flaccida Sweet & $\begin{array}{l}\text { Endemic to CFR, locally } \\
\text { frequent }\end{array}$ & 2 & & & & & & 2 & \\
\hline Moraea gawleri Spreng. & $\begin{array}{l}\text { South Western Coast of South } \\
\text { Africa, frequent }\end{array}$ & & & & & 1 & & 2 & \\
\hline $\begin{array}{l}\text { Moraea tripetala (L.f.) Kew } \\
\text { Gawl. }\end{array}$ & $\begin{array}{l}\text { Western Cape of South Africa } \\
\text { and adjacent areas, frequent }\end{array}$ & & & & & & & & 1 \\
\hline Ornithogalum thyrsoides Jacq. & $\begin{array}{l}\text { Western Cape and adjacent } \\
\text { areas, frequent }\end{array}$ & 1 & & & & & & & \\
\hline $\begin{array}{l}\text { Pterygodium catholicum (L.) } \\
\text { Sw. }\end{array}$ & $\begin{array}{l}\text { Endemic to renosterveld, CFR, } \\
\text { frequent after fire }\end{array}$ & 2 & 1 & 2 & 3 & 1 & 2 & 5 & 4 \\
\hline $\begin{array}{l}\text { Sparaxis villosa (Burm.f.) } \\
\text { Goldblatt }\end{array}$ & $\begin{array}{l}\text { Endemic to the West Coast, } \\
\text { CFR }\end{array}$ & & & 1 & 1 & & 2 & 2 & 3 \\
\hline $\begin{array}{l}\text { Spiloxene capensis (L.) } \\
\text { Garside }\end{array}$ & $\begin{array}{l}\text { Endemic to the coastal areas } \\
\text { of the CFR, locally frequent }\end{array}$ & & & & & & & & 1 \\
\hline $\begin{array}{l}\text { Spiloxene serrata (Thunb.) } \\
\text { Garside }\end{array}$ & West Coast of South Africa & & & & 1 & & 1 & 3 & 3 \\
\hline $\begin{array}{l}\text { Trachyandra muricata (L.f.) } \\
\text { Kunth }\end{array}$ & $\begin{array}{l}\text { Southern Namibia to SW Cape } \\
\text { of South Africa }\end{array}$ & & & & & & & & 1 \\
\hline Tulbaghia capensis L. & $\begin{array}{l}\text { Endemic to the coastal areas } \\
\text { of the CFR, locally frequent }\end{array}$ & & & & & & & & 2 \\
\hline
\end{tabular}




\section{References}

Bolger D.T., 2007. Spatial and temporal variation in the Argentine ant edge effect: Implications for the mechanism of edge limitation. Biol. Conserv. 136: 295-305.

Bragg C.J., Donaldson J.D. \& Ryan P.G., 2005. Density of Cape porcupines in a semi-arid environment and their impact on soil turnover and related ecosystem processes. J. Arid Environ. 61: 261-275.

Buys B., 1987. Competition for nectar between Argentine ants (Iridomyrmex humilis) and honeybees (Apis mellifera) on black ironbark (Eucalyptus sideroxylon). S. Afr. J. Zoo. 22: 173-174.

Cadenasso M.L. \& Pickett S.T.A., 2000. Linking forest edge structure to edge function: mediation of herbivore damage. J. Ecol. 88: 31-44.

Christian C.E., 2001. Consequences of a biologival invasion reveal the importance of mutualism for plant communities. Nature 413: 635-639.

De Villiers A.J., van Rooyen M.W. \& Theron G.K., 2003. Germination strategies of Strandveld Succulent Karoo plant species for revegetation purpose: III. Effect of relative humidity and storage site on seed viability. S. Afr. J. Plant Soil 20: 157-160.

Donaldson J., Nänni I., Zachariades C. \& Kemper J., 2002. Effects of fragmentation on pollinator diversity and plant reproductive success in renosterveld shrublands of South Africa. Conserv. Biol. 16: 12671276.

Fernández C., Acosta F.J., Abellá G., López F. \& Díaz M., 2002. Complex edge effect fields as additive processes in patches of ecological systems. Ecol. Model. 149: 273-283.

Galil J., 1970. Studies on the survival of dicotyledonous cormous weeds in ploughed fields. J. Appl. Ecol. 7: 61-65.

Hammouda S.K., Heneidy S.Z. \& El-Kady H.F., 2003. Effect of ploughing on plant species abundance and diversity in the northwestern coastal desert of Egypt. Biodivers. Conserv. 12: 749-765.

Harrison S. \& Bruna E., 1999. Habitat fragmentation and large-scale conservation: What do we know for sure? Ecography 22: 225-232.

Hester A.J. \& Hobbs R.J., 1992. Influence of Fire and Soil Nutrients on Native and Non-Native Annuals at Remnant Vegetation Edges in the Western Australian Wheatbelt. J. Veg. Sci. 3: 101-108.

Holl K.D. \& Lulow M.E., 1997. Effects of species, habitat, and distance from edge on post-dispersal seed predation in a tropical rainforest. Biotropica 29: 459-468.

Hurlbert S., 1984. Pseudoreplication and the design of ecological field experiments. Ecol. Monogr. 54: 187-211.

Jules E.S. \& Rathcke B.J., 1999. Mechanisms of reduced Trillium recruitment along edges of old-growth forest fragments. Conserv. Biol. 13: 784-793.

Kemper J., Cowling R.M. \& Richardson D.M., 1999. Fragmentation of South African renosterveld shrublands: effects on plant community structure and conservation implication. Biol. Conserv. 90: 103111.

Kongor R.Y., 2009. Plant response to habitat fragmentation: clues from species and functional diversity in three Cape lowland vegetation types of South Africa. Ph.D. Thesis, University of Stellenbosch.
Krug C.B. \& Krug R.M., 2007. Restoration of old fields in Renosterveld: A case study in a mediterraneantype shrubland of South Africa. In: Cramer V.A. \& Hobbs R.J. (eds), Old Fields: Dynamics and Restoration of Abandoned Farmland. Island Press, Washington: 265-285.

Krug R.M., Krug C.B., Iponga D.M., Walton B.A., Milton S.J., Newton I.P., Farley N. \& Shiponeni N.N., 2004. Reconstructing West Coast Renosterveld: Past and present ecological processes in a Mediterranean shrubland of South Africa. In: Arianoutsou M. \& Papanastasis V. (eds), Proceedings of the 10th MEDECOS conference. Rhodes, Greece, Millpress, Rotterdam: 120-132.

Lach L., 2007. A mutualism with a native membracid facilitates pollinator displacement by Argentine ants. Ecology 88: 1994-2004.

Laurance W.F., 1994. Rainforest fragmentation and the structure of small mammal communities in tropical Queensland. Biol. Conserv. 69: 23-32.

López-Barrera F., Newton A. \& Manson R.H., 2005. Edge effects in a tropical montane forest mosaic: experimental tests of post-dispersal acorn removal. Ecol. Res. 20: 31-40.

Low A.B. \& Rebelo A.G., 1996. Vegetation of South Africa, Lesotho and Swaziland, in Department of Environmental Affairs and Tourism. Pretoria: 1-85.

Matlack G.R., 1993. Microenvironment variation within and among forest edge sites in the eastern United States. Biol. Conserv. 66: 185-194.

McDowell C. \& Moll E., 1992. The influence of agriculture on the decline of West Coast Renosterveld, South-western Cape, South Africa. J. Environ. Manag. 35: 173-192.

Meiners S.J., Pickett S.T.A. \& Handel S.N., 2002. Probability of tree seedling establishment changes across a forest-old field edge gradient. Am. J. Bot. 89: 466-471.

Midoko-Ipongo D., Krug C.B. \& Milton S.J., 2005. Competition and herbivory influence growth and survival of shrubs on old fields: Implications for restoration of renosterveld shrubland. J. Veg. Sci. 16: 685-692.

Moll E.J., Campbell B.M., Cowling R.M., Bossi L., Jarman M.L. \& Boucher C., 1984. A description of major vegetation categories in and adjacent to the Fynbos Biome, in: South African National Science Report 83: 1-29.

Muhl S., 2008. Alien grass invasion of Renosterveld: Influence of soil variable gradients. M. Sc. Thesis, University of Stellenbosch.

Murcia C., 1995. Edge effects in fragmented forests: implications for conservation. Trends Ecol. Evol. 10: 58-62.

Newton I.P. \& Knight R.S., 2005. The use of Landsat imagery for the identification of the remaining West Coast Renosterveld fragments, Western Cape Province, South Africa. S. Afr. J. Bot. 71: 67-75.

Ostfeld R.S., Manson R.H. \& Canham C.D., 1997. Effects of rodents on survival of tree seeds and seedlings invading old fields. Ecology 78: 1531-1542.

Pauw A., 2004. Variation in pollination across a fragmented landscape at the Cape of Africa. Ph.D. Thesis, University of Cape Town.

Pauw A., Bond W.J. \& Hawkins J.A., 2004. Reconstruction of a historical pollination landscape reveals the disruption of mutualisms in small conservation areas. In: Arianoutsou M. \& Papanastasis V. (eds), MEDECOS. Rhodes, Greece, Millpress: Rotterdem. 
Picker M.D. \& Samways M.J., 1996. Faunal diversity and endemicity of the Cape Peninsula, South Africa - a first assessment. Biodivers. Conserv. 5: 591-606.

Piessens K., Honnay O., Devlaeminck R. \& Hermy M., 2006. Biotic and abiotic edge effects in highly fragmented heathlands adjacent to cropland and forest. Agric. Ecosyst. Environ. 114: 335-342.

Pressey R.L., Johnson I.R. \& Wilson P.D., 1994. Shades of irreplaceability: towards a measure of the contribution of sites to a reservation goal. Biodivers. Conserv. 3: 242-262.

Pressey R.L., Possingham H.P. \& Margules C.R., 1996. Optimality in reserve selection algorithms: when does it matter and how much? Biol. Conserv. 76: 259-267.

Procheş Ş., Cowling R.M. \& du Preez D.R., 2005. Patterns of geophyte diversity and storage organ size in the winter-rainfall region of southern Africa. Divers. Distrib. 11: 101-109.

Procheș Ş., Cowling R.M., Goldblatt P., Manning J.C. \& Snijman D.A., 2006. An overview of the Cape geophytes. Biol. J. Linn. Soc. 87: 27-43.

Rebelo A.G., 1995. Renosterveld: Conservation and research. In: Low A.B. \& Jones F.E. (eds), The sustainable use and management of Renosterveld remnants in the Cape Floristic Region (Proceedings of a Symposium). Flora Conservation Committee, Botanical Society South Africa, Kirstenbosch, Cape Town: 32-42.

Rebelo A.G., Boucher C., Helme N., Mucina L. \& Rutherford M.C., 2006. Fynbos Biome. In: Mucina L. \& Rutherford M.C. (eds), The Vegetation of South Africa, Lesotho and Swaziland. National Biodiversity Institute, Pretoria.

Reichman O.J. \& Jarvis J.U.M., 1989. The Influence of Three Sympatric Species of Fossorial Mole-Rats (Bathyergidae) on Vegetation. J. Mammal. 70: 763771.

Ries L., Fletcher R.J.J., Battin J. \& Sisk T.D., 2004. Ecological responses to habitat edges: mechanisms, models, and variability explained. Annu. Rev. Ecol. Evol. Syst. 35: 491-522.

Ruiters C., 2001. Biogeographical and conservation analysis of geophytes in the winter rainfall region of the Fynbos Biome, a Mediterranean-type ecosystem of South Africa. Thesis, University of the Western Cape.

Santos T. \& Telleria J.L., 1994. Influence of forest fragmentation on seed consumption and dispersal of Spanish juniper - Juniperus thurifera. Biol. Conserv. 70: $129-134$

Saunders D.A., Hobbs R.J. \& Margules C.R., 1991. Biological consequences of ecosystem fragmentation: A review. Conserv. Biol. 5: 18-32.

Shiponeni N.N., 2003. Dispersal of seeds as a constraint in revegetation of old fields in Renosterveld vegetation in the Western Cape, South Africa. M. Sc. Thesis, University of Stellenbosch.

Skinner J.D. \& Smithers R.H.N., 1990. The mammals of the Southern African subregion. University of Pretoria Press, Pretoria.

Stock W.D., Bond W.J. \& Le Roux D., 1993. Isotope evidence from soil carbon to reconstruct vegetation history in the south-western Cape Province. S. Afr. J. Sci. 89: 153-154.

Suarez A.V., Bolger D.T. \& Case T.J., 1998. Effects of fragmentation and invasion on native ant communities in coastal southern California. Ecology 79: 2041-2056.

Talbot W.J., 1947. Swartland and Sandveld. Oxford University Press, Cape Town.

Visser D., Wright M.G. \& Giliomee J.H., 1996. The effect of the Argentine ant, Linepithema humile (Mayr) (Hymenoptera: Formicidae), on flower-visiting insects of Protea nitida Mill. (Proteaceae). Afr. Entomol. 4: 285-287.

Vlok J.H.J., 1988. Alpha diversity of lowland fynbos herbs and various levels of infestation by alien annuals. S. Afr. J. Bot. 54: 623-627.

von Hase A., Rouget M., Maze K. \& Helme N., 2003. A fine-scale conservation plan for Cape lowlands Renosterveld: Technical Report (Main Report). In: CCU 2/03. Cape Conservation Unit: Botanical Society of South Africa.

Walton B.A., 2006. Vegetation patterns and dynamics of Renosterveld at Agter-Groenberg Conservancy, Western Cape, South Africa. Thesis, University of Stellenbosch. 